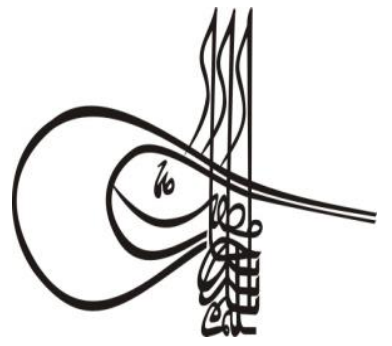

Received/Geliş: 10.02 .2019

\section{Turkiglo Studies Educational Sciences}

Volume 14 Issue 3, 2019, p. 321-334

DOI: 10.29228/TurkishStudies. 22900

ISSN: 2667-5609

Skopje/MACEDONIA-Ankara/TURKEY

Research Article / Araştırma Makalesi

Article Info/Makale Bilgisi

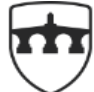

INTERNATIONAL BALKAN UNIVERSITY

EXCELLENCE FOR THE FUTUR IBU.EDU.MK

Gor Report Dates/Rapor Tarihleri: Referee 1 (10.04.2019)-Referee 2 (21.04.2019)- Referee 3 (20.05.2019)

This article was checked by turnitin.

\title{
TÜRKÇE ÖĞRETMENLERİNIN DRAMA KULLANIM DURUMLARI (Zonguldak İli Örneği)
}

\author{
Ahmet ASAR* - Filiz METE**
}

\begin{abstract}
Öz
Bu çalışmayla, Türkçe öğretmenlerinin derslerde drama kullanım durumlarının ve kullanım sonucunda gözlemledikleri etkilerin neler olduğunun belirlenmesi amaçlanmaktadır. Araştırma, nitel araştırma kapsamında yer alan görüşme yöntemi ile veri toplama aracı olarak araştırmacılar tarafından oluşturulan yarı yapılandırılmış görüşme formları kullanılarak gerçekleştirilmiştir. Türkiye Cumhuriyeti Milli Eğitim Bakanlığına bağlı Zonguldak ili ortaokullarında görev yapan gelişigüzel seçilmiş 54 Türkçe öğretmeni ile görüşülmüştür. Görüşmelere katılan öğretmenlerin bilgi ve görüşleri görüşme formlarına kaydedilmiş ve sonrasında formlar doküman analizi ile incelenmiştir. Öğretmenlerin $\% 94,4$ 'ünün derslerde drama kullandığı \%5,6`sının kullanmadığ ortaya çıkmıştır. Derslerinde drama kullanmayan öğretmenlerin kullanmama sebeplerine bakıldığında bir öğretmenin kendinden kaynaklı olarak dramayı kullanmadığı, bir öğretmenin drama eğitimi almadığından drama kullanmadığı ve bir öğretmenin ise öğrencileri sınava hazırladığı için drama kullanmadığı ortaya çıkmaktadır. Sonuç olarak öğretmenlerin neredeyse tamamına yakınının derslerinde eğitici dramayı kullandıkları anlaşılmaktadır. Dramanın faydaları konusunda öğretmen görüşlerinin dağılım oranı şu şekilde ortaya çıkmıştır: İletişim becerilerini geliştirme $\% 63$, öğretimin etkililiğini sağlama \%50, özgüven geliştirme $\% 46$, duygudaşlık geliştirme \%31, takım olma bilinci geliştirme \%27, derse katılımı sağlama \%24, hayal gücü ve yaratıc1lığ1 artırma \%16, duygusal zekâ ve kişiliğin gelişimine katkı sağlama \%15 oranındadır. Ancak öğretmenlerin drama etkinliklerinin eleştirel düşünme ve problem çözme becerisine katkısı, ahlaki değerleri fark etmeye yardımcı olması, eski
\end{abstract}


bilişsel görüşleri gözden geçirmeye imkân vermesi, psikolojik sorunların çözümüne katkısı, bireyin kendini tanımasına katkısı hususlarına hiç değinmedikleri tespit edilmiştir.

Anahtar Kelimler: Türkçe öğretimi, drama, eğitici drama, dramanın faydaları

\title{
DRAMA USAGE STATUS OF TURKISH TEACHERS (The Case of Zonguldak Province)
}

\begin{abstract}
In this study, it is aimed to determine the use of drama to the Turkish language teachers in the courses and the effects they observed as a result of their use. The research was carried out by using semistructured interview forms formed by the researchers as a data collection tool with the interview method included in the qualitative research. 54 Turkish teachers working in schools affiliated to MoNE were interviewed. The information and opinions of the teachers who participated in the interviews were recorded in the interview forms and then the forms were analyzed by document analysis. It was determined that $51(\% 94,4)$ teachers were used drama in their course, but $3(\% 5,6)$ were not used. When the teachers who did not use drama in their classes asked why they did not use it, it was revealed that a teacher did not use them as self-induced, one did not receive drama training and one had to prepare her students to the exam. As a result, it is understood that almost all of the teachers used educational drama in their lessons.

When asked about the benefits of using drama, the distribution of teachers' views on the benefits of drama has emerged as follows: developing communication skills (63\%), increase the effectiveness of teaching $50 \%$, developing self-confidence $46 \%$, developing empathy $31 \%$, improving team awareness $27 \%$, increasing the participation rate of course activities $24 \%$, improving imagination and creativity $16 \%$, to contribute to emotional intelligence and personality development is $15 \%$. However, it has been found that teachers do not mention the contribution of drama activities to critical thinking and problem solving skills, to help them to realize moral values, to allow to revise the old cognitive views, to contribute to the solution of psychological problems and to contribute to the self-recognition of the individual.
\end{abstract}

\section{STRUCTURED ABSTRACT}

Drama as a term is based on the Greeks, and in the modern sense it is true that drama is based on the Greeks. However, in terms of drama elements such as imitation and animation, the history of drama goes as far back as human history. Drama which is an independent branch of art as someone is the revival of emotions, thoughts with gesture, mimicry, movement and revival with words. But It is considered a commonly used method in the field of education. Drama is also an important learning 
and effective teaching method. It can be said that drama is an effective method in many areas, from creativity to critical thinking, from collaborative work to moral values. While the cost of learning by doing is the most heavily paid form of learning, it is actually the most permanent way of learning. Thanks to drama, the child gets to know his life better like a play activity and gets the opportunity to live different experiences. Drama in our country started to be applied in schools of the Ottoman Empire. Making maximum use of educational drama in Turkish lessons helps students develop their language skills and enrich their vocabulary.

In this study, it is aimed to determine the drama usage situations of Turkish teachers and the effects they observed as a result of the usage. For this purpose, the definition of drama, the types of drama and the benefits of drama were investigated. It is aimed to reveal the awareness of Turkish teachers about the kind of drama activities they use and the benefits of these activities.

The research was carried out by using the interview method within the scope of qualitative research and semi-structured interview forms created by the researchers as a data collection tool. Before the interviews, a semi-structured form was created by the researcher with the questions thought to serve the purpose. The form was directed to two Turkish teachers and two field experts and asked for their opinion on whether they would serve the purpose or not.

In this context, the following questions were asked to the participants and the answers were recorded:

Did you receive any training in drama? Why and where?

Do you use drama in educational activities? If yes, in what circumstances and why?

Do you think the use of drama in education contributes to student development? If yes, what about and how?

The research was carried out with 54 easily accessible Turkish teachers working in schools affiliated to MoNE in central and districts of Zonguldak. The interview was conducted with 38 female and 16 male teachers. Participation in the interviews is strictly voluntary. Interviewer names are coded. The information and opinions of the teachers who participated in the interviews were recorded on the interview forms and then the forms were examined with document analysis.

It was seen that $50(92.6 \%)$ teachers were at the undergraduate level and $4(7.4 \%)$ teachers were at the graduate level. The average length of service for the interviewed teachers is approximately 12 years. It was found out that $41(75.9 \%)$ teachers received drama education and 13 $(24.1 \%)$ teachers did not receive drama education. It was found out that $51(94.4 \%)$ teachers used drama in the lessons and $3(5.6 \%)$ teachers did not use drama. Almost all of the teachers interviewed agree that drama activities can be used easily in every stage of the Turkish lesson. The vast majority of teachers seem to be aware of the benefits of drama, and it turns out that almost all of them use drama in their lessons. However, it should not be ignored that teachers use drama as a text animation activity with a rate of $33 \%$.

As it is known, Turkish course is not a knowledge course but a skill course. In this aspect, it is based on the practices related to life and it 
hosts them. With this method, the language can be taught directly in the field of use along with its rules. disorders of expression, language mistakes, idioms and proverbs, even abstract meaningful complex poems can be easily explained with drama, all the beauties of language can be taught by keeping alive.

It was found out that $94.4 \%$ of the teachers used drama in the lessons and $5.6 \%$ did not. Although it is seen that the teachers who use drama in their courses use activities for different purposes in many different subjects, in general terms, drama activities are revived according to the text, grammar-based animation, writing texts in writing; telephone conversations, introductory conversations, convincing conversations.

Looking at the reasons why teachers do not use drama in their classes, it is seen that a teacher does not use drama as a result of selfeducation, a teacher does not use drama because he does not receive drama education and a teacher does not use drama because he prepares students for the exam. As a result, it is understood that almost all of the teachers use educational drama in their lessons. However, no acceptable data on its effectiveness could be reached.

The distribution of teachers' views on the benefits of drama is as follows: Developing communication skills 63\%, Ensuring the effectiveness of teaching $50 \%$, Developing self-confidence $46 \%$, Developing sympathy $31 \%$, Developing team awareness $27 \%$, Participation in class 24\%, Imagination and $16 \%$ increase in creativity, $15 \%$ contribute to the development of emotional intelligence and personality. However, it was found that teachers' drama activities did not address the contributed to critical thinking and problem-solving skills, helped to recognize moral values, enabled to review old cognitive views, contributed to the solution of psychological problems, and the individual's self-recognition.

Keywords: Teaching Turkish, drama, educational drama, the benefits of drama.

\section{GİRIŞ}

Drama terim olarak Yunanlılara dayandırılmaktadır ve modern anlamda dramanın Yunanlılara dayandırılması doğrudur lakin taklit, canlandırma gibi drama öğeleri açısından meseleye bakılınca drama tarihinin insanlık tarihi kadar gerilere götürülebileceği görülür (Kara, 2010). Drama kavramı eski Yunanlılarda yapmak, etmek, eylemek anlamlarına gelen 'dran' kelimesinden gelmektedir. Nutku'ya (1983) göre dram sanatı sahnelenebilecek şekilde yazılmış yazınsal değere sahip eserdir. San (1990) dramanın tiyatro biliminde özetlenmiş eylem anlamına geldiğini belirtmektedir. Türkçe sözlükte Latince isim olarak acıklı, hüzünlü, komik olayları sahnelenmek üzere kaleme alınan sahne oyunu (TDK, 1983) şeklinde tanımlanırken Kavcar'a (1988) göre drama günümüzde genellikle oyun ve tiyatro sanatı anlamında kullanılmakta ve oyunlaştırma, yaşanırlık kazandırma anlamına gelmektedir.

Drama, aynı zamanda önemli bir öğrenme yöntemidir. Soyut kavramların somuta dönüştürülebildiği, kavramlar arası ilişki ve bağlantıların görünür kılınabildiği bir etkinlik temelidir. O’Neill ve Lambert (1990) dramanın hayal gücünün olabildiğince genişletilebildiği bir alan olduğunu belirtmektedir. McCaslin (1980), dramanın, günümüzde önemli bir öğretim yöntemi olduğuna dikkat 
çekerek bir yöntem olarak dramanın yaratıcılıktan eleştirel düşünmeye, işbirlikçi çalışabilmekten ahlaki değerlere kadar birçok alanda etkili olduğunu söylemektedir.

Drama duyguların, düşüncelerin jest, mimik, hareket ve sözle canlandırılması, kimilerince bağımsız bir sanat dalı şeklinde görülürken eğitim alanındaysa sık olarak kullanılan bir yöntem olarak karşımıza çıkmaktadır. San (1991) drama yöntemi ile öğretimi: duyguların, düşüncelerin, yaşantıların kimi zaman soyut kavramların drama ve tiyatro teknikleri ile grup çalışması şeklinde canlandırılması olarak belirtirken bu süreç içerisinde bireyin bilişsel örüntülerini tekrar gözden geçirmesine de değinmektedir.

Günümüzde drama; yaratıcı drama, eğitici drama, psikodrama ve sosyodrama olmak üzere dört alt başlık altında (Ünal, 2006; Karadağ ve Çalışkan, 2005) ele alınmaktadır.

Yaratıcı drama: Yazılı bir metine bağlı olmayan yaratıcı dramanın sahnelenmek gibi bir amacı bulunmamaktadır. Bir liderin rehberliğindeki katılımcıların yaşamış ya da hayal etmiş olduklarına ait duygu ve düşüncelerini bir olay merkezinde doğaçlama dramatik oyunlar olarak yansıtmasıdır (Çalışkan \& Karadağ, 2005).

Psikodrama: Psikolojik alanlarda problem çözme amaçlı uygulanan telkin ve tedavi aracıdır (Kaner, 1990).

Sosyodrama: Berdel, erken yaşta zorla evlendirme, başlık parası vb. toplumsal sorunların ele alındığı iletişimi, güvenmeyi ve rahatlama çalışmaları gibi geniş bir kapsamı içeren drama çalışmalarıdır (Bozdağan, 2003).

Eğitici Drama: Öğretmen gibi yetişkin bir liderce temel kuralları belirlenmiş ancak mümkün olduğunca esnek davranıma izin verilen ve çocuklarca grup oyunu gibi görülebilen etkinliklerdir (Önder, 2004). Gönen'e (1992) göre eğitici dramanın temel kurallarının belirlenmesi durumu eğitimin amaçlarıyla sınırlandırma olarak belirtilmekte ve kapsamın eğitici tarafindan çizilmesi şeklinde açıklanmaktadır.

Doğal olarak eğitimcileri en çok ilgilendiren drama türü, eğitici dramadır.

Eğitici drama; "önceden belirlenmiş açık ve net eğitim amaçları olan, tüm çocukların öğretmenleri ile birlikte, daha çok büyük motor hareketlerle yaptıkları, ifade etmeye, rol oynamaya, canlandırmaya ve tartışmaya dayalı grup etkinlikleridir" (Önder, 2004: 32) şeklinde tanımlarken eğitim amaçları ifadesinin açıkça öğrenmeye, anlamaya atıfta bulunduğu; önceden belirlenmiş ifadesi de eğitici dramanın program kazanımlarından bağımsız olmadığını göstermektedir. "Oyun, sadece bir araç olarak kullanılmaktadır” (McCastlin, 2000: 13). Bağdatlı’ya (2010) göre de dramanın öğretim yöntemi olarak farkı öğrenilecek şeyi yaşatmasıdır.

Yaparak yaşayarak öğrenme bedeli en ağır ödenen öğrenme şekli olsa da aslında en kalıcı öğrenme yoludur. Çocuk drama sayesinde sevdiği bir oyun etkinliği gibi yaşantısını daha iyi tanır ve farklı deneyimler yaşama firsatını elde eder.

Ülkemizde Osmanlı Devleti zamanındaki okullarda uygulanmaya başlanan drama; "Bir eylemin, bir olayın, duygunun, çeşitli rollerin, bir kavramın, konunun ya da öykünün, hatta şiirin, canlı ya da cansız varlıkların sözel ve sözsüz, kendiliğinden davranışlarla, taklit yolu ile temsili olarak ifade edilmesi, canlandırılmasıdır. " (Önder, 2000:32).

Psikodramada da başvurulan bu yol, daha çok "karakterin özelliklerini ve hislerini canlandırma" (Şahin, 2003: 152) olarak tanımlanmaktadır. Rol oynama tekniği ile hayatta karşılaşılan pek çok durum yapay bir ortamda yaşanabilmektedir. "Rol oynama doğaçlama olarak oynanabileceği gibi, bir metne bağlı olarak da gerçekleştirilebilmektedir" (Bağdatlı, 2010: 122). Mesela bir çocuk kendisi dışındaki insanların rolünü canlandırarak onlarla empati kuracak ve onların duygularını daha iyi anlama firsatı 
bulacaktır. Böylece çocuğun bakış açısı da gelişecek, olaylara ve kişilere farklı açılardan bakma becerisi kazanacaktır. Hatta çocukların süreç içerisinde üstlendikleri rolleri değiştirerek farklı rolleri de canlandırması duygudaşlık kazanmasında etkili olacaktır. Bazen drama etkinliklerine dans ve müzik de eklenebilir. Bu tarz zenginleştirmeler etkiyi artıracak motivasyonu yükseltecektir.

Sözcük kullanmadan yapılan canlandırma veya oyunlar pandomim olarak isimlendirilmektedir (Aral, 2000). Mc Castlin (1990) çocukların genel olarak duygu ve düşüncelerini bedenlerini kullanarak ifade ettiklerini ve bunun 5-6 yaş çocukların için doğal bir yol olduğunu belirtmektedir. Bu doğal yol ile yapılacak olan etkinlikler dikkat çekici olabileceği gibi "Bu yolla öğrencilerin iletişim becerileri, özellikle de jest ve mimiklerin oyun içinde kullanılmasıyla, sözsüz iletişim becerileri de gelişmektedir" (Kandır, 2003: 113). Ayrıca öğrencilerin duygularını ifade etmeleri için doğaçlama rol yapma etkinlikleri de bulunmaktadır ve geleneksel sayılabilecek kukla oyunları da drama etkinlikleri kapsamında değerlendirilebilecek etkinliklerdendir.

Oyunlar, çocukların doğuştan getirdiği bir ihtiyaç ve her ortamda rahatlıkla katılabilecekleri sosyal durumlardır. Eğitici dramanın oyunsu yönü öğrencileri aktif hale getirmekteyken bir diğer özelliği de öğretmenin rehberliğinde ortaya konulmasıdır (İsmihan, 1992). Dramanın oyun üzerine kurulu olmasından ötürü dersler monotonluktan kurtularak daha eğlenceli hale gelebilir.

"Türkçe derslerinde eğitici dramadan azamî ölçüde yararlanmak, öğrencilerin dil becerilerinin gelişmesine ve sözcük dağarcıklarının zenginleşmesine hizmet eder" (Şimşek ve Topal, 2006: 277; Şimşek, Topal, Maden ve Şahin, 2010: 107).

"Drama yönteminde bütün duyu organları etkin bir şekilde kullanıldlğı için çocuğun algılama, dinleme, konuşma, vücut dilini kullanarak anlatma ve yorumlama gibi dil ve iletişim becerileri gelişir. Çocuk anlatım düzeyini olumsuz etkileyen utangaçlı, çekingenlik gibi duygulardan arınır. Drama somut bir ortamda yapıldiğından soyut dil kavramlarının anlaşıllp somutlaştırılmasına yardımcı olur. Çocuğun düs gücünü ve estetik duygusunu gelişstirerek onun, dilin iyi kullanımı, güzel kullanımı gibi kavramları daha sağglılı algılamasını ve yorumlamasını sağlar" (Er, 2003: 253).

"Eğitimde drama konusuna ilk kez eğilen kişi 20. yüzyılın başlarında Harriet-Finlay Johnson'dır ve kullanılmaya başlanmasıyla öğrenmede kalıcılık artmış, yaparak yaşayarak öğrenme sayesinde öğrencilerin derslere karşı tutumları da olumlu yönde gelişmiştir" (Çebi, 1996: 127). Sağlam (1997) Johnson'ın bir köy okulunda öğretmen olduğunu, çocukların gerçekten görerek ve yaparak daha iyi öğrendiklerine inandığını, öğrenmeyi zevkli bir hâle getirerek öğretilebilecek her konuyu (tarih, Shakespeare, coğrafya ve matematik) dramatik eyleme uyarlamaya başladığını ve dramayı drama olarak öğretmek için değil, onu bilgiyi aktarmak için kullandığını belirtmektedir. Ayrıca dramanın asıl cevheri oyuna dayalı bir grup çalışması olması ve çocukların kendi deneyimlerini ve bakış açılarını diğerleriyle karşılaştırıp nerelerde farklı olduklarını, hangi konularda benzeştiklerini fark etmeleri ve bunları kabullenmeleridir (Kara ve Çam, 2007:147).

Dil öğretiminin amaçlarından olan sözlü ifade edebilme, dinleme, okuma, kendine güven, eleştirel düşünme, dilin farklı biçimlerini kullanabilme (Bayram, 1999; Gönen ve Dalkılıç, 1999) gibi becerilerin kazanımında eğitici drama kullanımı etkili olabilmektedir. "Dramatizasyon dört temel dil becerisini geliştirir" (Ayranc1, 2019: 131). Nitekim Şimşek, Topal, Maden ve Şahin'e, (2010) göre de bu kazanımları elde etmeye yönelik çalışmalar içinde dramada kullanılan teknikler en çok kullanılan tekniklerdir. Bu anlamda "Yaşamda var olan bir olayın yeniden kurgulanması, yaşam gerçekliğinin yansılanması, düzenlenen bu gerçekliğin canlandırılması ve yaşamı farklı kılan, yaşamı etkileyen düşünce, hareket olan aksiyondan oluşan drama sanatı" (Nutku 2001, 28) etkili bir öğretim yöntemi olarak kullanılmaktadır. Öğretim yöntemi olarak dramada oyun özellikleri belirginken Kaygana ve Yapıcı'nın (2010) belirttiği üzere tiyatroya halkı eğitme görevi yüklendiğinden uygulama aşamasında da tiyatro izleri belirginleşmektedir. "Türkçe dersinin temel amacının anlama ve anlatma becerilerini 
geliştirmek olduğu dikkate alındığında bu becerilerin geliştirilmesi için en uygun yöntemlerden birisi eğitici dramadır" (Çalışkan ve Karadağ 2005: 94).

Drama etkinliklerinin Türkçe dersleriyle bağlantılı olarak dil gelişimine katkısını Stabler (1978), hedefler hâlinde şöyle sıralamıştır:

"1- Konuşurken kendine güvenin gelişmesi,

2- Konuşmanin gelişmesi,

3-Akıcılığın gelişmesi,

4- Kelime hazinesinin zenginleşmesi,

5- Fikirlerin dile getirilmesi,

6- İnsanlarla ilişsi kurma becerisinin kazanılması,

7- Dinleme becerisinin kazanılmasl,

8- Farklı durumlarda farklı dilin kullanılması,

9- Tanımlama, tartışma ve değerlendirme becerisinin gelişmesi” (akt. Ömeroğlu, 1991: 89).

Özellikle küçük yaştaki öğrenciler için derslerini daha eğlenceli ve canlı hâle getiren drama uygulamaları, sözlü anlatım becerilerinin geliştirilmesinde önemli bir yere sahiptir.

Başçı ve Gündoğdu (2011) çalışmalarında drama kullanmanın yararlarını literatürde şu şekilde özetlendiğini belirtmektedirler: Yaratıcılığı geliştirir, eleştirel düşünme becerisi kazandırır, estetik gelişim sağlar, işbirlikçi çalışma alışkanlığı kazandırır, ahlaki değerlerin farkedilmesine zemin hazırlar, sosyal gelişimi destekler, özgüveni artırır, dilsel gelişime katkıda bulunur, tecrübe kazanmayı sağlar, hayal gücünü geliştirir ve duygudaşlık kazandırır.

Sonuç olarak literatürde dramanın faydaları konusunda şu noktalara değinildiği ortaya çıkmaktadır:

-Drama hayal gücünü zenginleştir.

-Soyut kavramların somutlaştırdığı için etkili bir öğretim yöntemidir.

-Yaratıcılık ve estetik gelişimi destekler

-Eleştirel düşünme ve problem çözme becerisi kazandırır.

-İşbirliği içinde çalışma yeteneği kazandırır.

- Sözlü ve sözsüz iletişim becerilerini geliştirir.

-Kelime hazinesini geliştirir.

-İfade becerilerini geliştirir.

-Konuşma dinleme becerisini geliştirir.

-Okuma becerisini geliştirir.

-Farklı durumlara göre dilin kullanımını öğretir.

-Ahlaki değerlerin farkına varılmasını sağlar.

-Eski bilişsel süreçlerin gözden geçirilmesine olanak sağlar.

-Psikolojik ve sosyolojik sorunların çözümünde yararlanılır.

Turkish Studies - Educational Sciences

Volume 14 Issue 3, 2019 
-Farklı bakış açılarını kazandırarak duygudaşlığın gelişmesini sağlar

-Dikkati artırır.

-Rahat ve eğlenceli bir ders ortamı oluşturmaya yardımcı olur.

-Bireyin kendini tanımasına yardımcı olur

$\mathrm{Bu}$ çalışmada, Türkçe öğretmenlerinin derslerde drama kullanım durumlarının ve kullanım sonucunda gözlemledikleri etkilerin neler olduğunun belirlenmesi hedeflenmiştir. Bu amaçla dramanın tanımı, dramanın türleri ve dramanın faydaları araştırılmış Türkçe öğretmenlerinin hangi tür drama etkinliklerini kullandıkları ve bu etkinliklerin faydaları konusunda farkındalıklarını ortaya koymak amaçlanmıştır. Bu bağlamda görüşme katılımcılarına aşağıdaki sorular yöneltilmiş ve cevaplar kayıt altına alınmıştır:

Drama konusunda her hangi bir eğitim aldınız mı? Neden? Nereden?

Eğitim etkinliklerinde drama kullanır mısınız? Evet, ise hangi durumlarda? Neden?

Sizce eğitimde drama kullanılmasının öğrenci gelişimine katkısı var mıdır? Evet, ise hangi konuda? Nas1l?

\section{Yöntem}

$\mathrm{Bu}$ araştırma nitel araştırma yöntem ve teknikleri kullanılarak yapılmıştır. Yıldırım ve Şimşek'e (2013) göre nitel araştırmalar, olayların ve algıların doğal ortamında gerçekçi ve bütüncül bir yaklaşımla görüşme ve doküman analizi benzeri yöntemlerle incelenmesidir.

Bu araştırmada nitel araştırma kapsamında yer alan görüşme yöntemi ile yarı yapılandırılmış görüşme formları kullanılarak gerçekleştirilmiştir. "Görüşme en az iki arasında sözlü olarak sürdürülen bir iletişim sürecidir ve bireylerin bakış açılarını, tecrübelerini, duygularını, algılarını saptayabilmek için güçlü bir yöntemdir" (Büyüköztürk, 2013). Görüşmeler öncesi araştırmacı tarafından amaca hizmet edeceği düşünülen sorularla yarı yapılandırılmış bir form oluşturulmuştur. Form iki Türkçe öğretmenine ve iki alan uzmanına yönlendirilerek amaca hizmet edip etmeyeceği hususunda görüş istenmiş ve onay alınarak kullanılmıştır. "Zaten yarı yapılandırılmış görüşmelerin araştırmacıya sunduğu en önemli kolaylık görüşmenin önceden hazırlanmış görüşme protokolüne bağlı olarak sürdürülmesi nedeni ile daha sistemli ve karşılaşılabilir bilgi sunmasıdır” (Yıldırım ve Şimşek, 2013).

Araştırma Zonguldak ili merkez ve ilçelerinde MEB'e bağlı okullarda görev yapan kolay ulaşılabilir 54 Türkçe öğretmeni ile gerçekleştirilmiştir. Gerçekleştirilen görüşmelerde katılım kesinlikle gönüllülük esasına dayanmaktadır. Görüşmelere katılan öğretmenlerin bilgi ve görüşleri görüşme formlarına kaydedilmiş ve sonrasında formlar doküman analizi ile incelenmiştir. Örnek olarak verilen öğretmen görüşleri Öğretmen1, Öğretmen2 şeklinde kodlanarak verilmiştir.

\section{Bulgu ve Yorumlar}

Görüşme $38 \quad(\% 70,4)$ kadın $16 \quad(\% 29,6)$ erkek toplam 54 Türkçe öğretmeni ile gerçekleştirilmiştir. $50(\% 92,6)$ öğretmenin lisans düzeyinde $4(\% 7,4)$ öğretmenin yüksek lisans düzeyi eğitim seviyesinde olduğu görülmüştür. Görüşme yapılan öğretmenlerin ortalama hizmet süresi yaklaşık 12 yıldır. En az hizmet süresine sahip öğretmenin çalışma süresi1 yıl iken en çok hizmet süresine sahip öğretmenin çalışma süresi 30 yıldır. $41(\% 75,9)$ öğretmenin drama eğitimi aldığ $13(\% 24,1)$ öğretmenin ise drama eğitimi almadığı ortaya çıkmıştır. $51(\% 94,4)$ öğretmenin derslerde drama kullandığı $3(\% 5,6)$ öğretmenin drama kullanmadığı ortaya çıkmıştır.

Derslerinde drama kullanmayan öğretmenlerin drama kullanmama sebeplerine bakıldığında Öğretmen 2'nin uygun şartları ve zamanı oluşturamadığını, Öğretmen 45'in drama eğitimi almadığı için 
drama kullanmadığını, Öğretmen 49'un ise 8. sınıflarda sınava yönelik hazırlık sebebiyle sürekli test çalışması yaptırdığından derslerde drama kullanmadığını belirttiği görülmektedir. Dramayı derslerinde kullanmayan öğretmenlerin üçünün de kadın olduğu, hizmet sürelerinin 15 yıldan az olduğu, eğitimlerinin lisans düzeyinde olduğu, iki öğretmenin drama eğitimi aldığı birinin ise almadığı ortaya çıkmaktadır. Sonuç olarak yalnız bir öğretmenin kendinden kaynaklı olarak dramayı kullanmadığı, bir öğretmenin drama eğitimi almadığından drama kullanmadığı ve bir öğretmenin ise öğrencileri sınava hazırladığı için drama kullanmadığı ortaya çıkmaktadır. Üç öğretmenin de dramanın öğrenci gelişimine katkısı olduğunu belirttiği; Öğretmen 45'in dramada beş duyu organının kullanılabildiğinden dramanın faydalı olduğunu belirtmesi dikkat çekicidir. Öğretmen 2'nin dramanın öğrencinin iletişim becerisine, duygudaşlık kurabilmesine katk1 sağlayabileceğini drama sayesinde derslerin daha eğlenceli geçebileceğini ve drama ile yapılan öğrenmenin daha kalıcı olabileceğini belirttiği görülmektedir. Öğretmen 49 ise dramanın; öğrencinin daha kolay öğrenmesini sağlayabileceğini, hayal gücünü artırabileceğini belirtmekte ve konuların somutlaştırılmasında drama kullanılabileceğini ifade etmektedir.

Derslerinde drama kullandığını belirten öğretmenlerin çok farklı konularda farklı amaçlarda etkinlik kullandıkları görülse de genel anlamda drama etkinliklerinin metin canlandırma, dilbilgisi konularına uygun canlandırma, yazma çalışmalarında metin oluşturma; telefon konuşmaları, tanışma konuşmaları, ikna edici konuşmalar şeklinde iletişim becerilerini geliştirme etkinlikleri şeklinde dramayı kullandıkları ortaya çıkmaktadır. Öğretmenlerin kullandığı etkinlik türleri ve konular aşağıdaki gibidir:

Tablo 1: Öğretmenlerin kullandığı drama etkinlikleri

\begin{tabular}{lll}
\hline Drama Türü & & \multicolumn{1}{c}{$f$} \\
\hline Yaratıcı drama & & 2 \\
\hline Psikodrama & & - \\
\hline Sosyodrama & & 8 \\
\hline Eğitici drama & Rol oynama & 11 \\
\cline { 2 - 3 } & Paralel çalışma & - \\
\cline { 2 - 3 } & Zihinde canlandırma & 1 \\
\cline { 2 - 3 } & Müzikle drama & 3 \\
\cline { 2 - 3 } & Rol değiştirme & 5 \\
\cline { 2 - 3 } & Kenardan yönlendirme & - \\
\cline { 2 - 3 } & Katılımcı liderlik & - \\
\cline { 2 - 3 } & Doğaçlama & 6 \\
\cline { 2 - 3 } & Duyusal algılama & - \\
\cline { 2 - 3 } & Dans draması & - \\
\cline { 2 - 3 } & Pandomim & 5 \\
\cline { 2 - 3 } & Öykü/olay canlandırma & 33 \\
\cline { 2 - 3 } & Resim yapma & 8 \\
\cline { 2 - 3 } & Kukla oyunları & 9 \\
\hline
\end{tabular}

Görüşmenin gerçekleştirildiği 54 Türkçe öğretmenine bir eğitim öğretim dönemi boyunca ne tür drama etkinlikleri yaptıkları sorulduğunda derslerde en çok öykü veya olay canlandırması (33) kullanıldığ 1 belirlenmiştir. Bunu rol oynama (11) etkinlikleri izlemektedir. Geleneksel tiyatromuz ortaoyunu ve Karagöz Hacivat ise kukla oyunları (9) olarak yine sıkça kullanılan etkinliklerdir. Görüşmede sosyodrama etkinliği (8) kadar resim yapma etkinliklerinin de (8) kullanıldığı belirlenmiştir. Derslerde doğaçlama (6), pandomim (5) ve rol değiştirme (5) etkinlikleri kullanan katılımcılar da yer almaktadır. Ayrıca müzikle drama (3) ve yaratıcı drama (2) etkinlikleri de gerçekleştiren öğretmenler 
olduğu belirlenmiştir. Sadece bir katılımcı ise zihinde canlandırma (1) etkinliği yaptırdığını bildirmiştir. Aşağıda görüşme sırasında anlatılan örnek etkinliklerden bazıları yer almaktadır:

Öğretmen15: Öğrencilere noktalama işaretlerini dă̆ıtarak 1. Kişili anlatımla kendi ăğzlarından görevlerini anlatmalarını istemiştim.

Öğretmen16: Sınıf içinde doğaçlama şiir düelloları yaptırıyorum. Ayrıca süreli ses eğitimleri (ses açma, karakter canlandırma) ve benzerlerini yaptırıyorum.

Sahne eğitimi, jest ve mimik kullanımını önemsiyorum. Sinıf içerisinde metin canlandırma ve oyun eğitimi yapmaktayım.

Öğretmen28: Dil Anne ve çocukları konuşturarak

Dil (Anne)

Çocukları (İsim, slfat, zarf...)

Konuya göre aralarında geçen konuşmalar.

Öğretmen50: Geçişli-geçişsiz fiilleri işlerken bir öğrenciyi trafik polisi olarak görevlendiririm. Öğrenci geçişli fiillerin yazılı olduğu fiilleri taşıyan öğrencilerin geçmesine izin verir, diğerlerine vermez.

Girdiğim sınıflarda özellikle "Filika" ve "Bilinç Koridoru" oyunlarını mutlaka oynatırım. Filika'da çocuklar Titanik'te olduğunu hayal eder. Değişik roller üstlenir. Birisi dünyaca ünlü bir beyin cerrahı olur, birisi Anadolu'da yaşayan yedi çocuklu bir kadın... Filikadaki tek kişilik bir yere binmek için iki dakikalık konuşma yapar. Kim rolünü en iyi şekilde canlandırır ve jüriyi ikna etmeyi başarırsa birinci seçilir.

"Bilinç Koridoru”nda ise dörder kişilik iki grup bir koridor oluşturur. Bir öğrenci seçilir. Bu öğrenciye iki önerme verilir. Örneğin birinci önermede "Yarın okulda hayatını etkileyecek bir sınavin var, bu yüzden okula gitmelisin", ikinci önermede "Yarın çok sevdiğin akrabaların bir günlügüne uzaktan gelecek, onları görmelisin." denir. Dört kişilik birinci grup birinci önermeyi, ikinci grup ikinci önermeyi savunur. Öğrenci eller üstten kenetlenerek oluşturulan koridordan geçerken iki grup tarafindan ikna etmeye çalışılır. Hangi grup düşüncesini daha iyi savunup ögrenciyi ikna ederse o grup kazanir.

Görüş̧me yapılan öğretmenlerin dramanın faydası konusundaki ağılıklı olarak ortak görüşleri drama iletişim becerilerini geliştirir, drama özgüveni geliştirir, drama duygudaşlığı geliştirir şeklinde ortaya çıkmaktadır. Öğretmenlerin dramanın faydaları konusunda ortak görüş oranına göre belirttikleri faydalar aşağıdaki şekilde ortaya çıkmaktadır: 


\begin{tabular}{|c|c|}
\hline Konu & $\mathrm{f} \%$ \\
\hline Kendini ifade etme becerisi geliştirmesi & $\% 15$ \\
\hline Hayal gücü ve yaratıcılığı geliştirmesi & $\% 16$ \\
\hline Aktif öğrenci katılımı sağlaması & $13 \% 24$ \\
\hline Takım bilinci kazandırması & $15 \% 27$ \\
\hline Empati geliştirmesi & $17 \% 31$ \\
\hline Özgüveni artırması & $25 \% 46$ \\
\hline Etkili öğretim sağlaması & $27 \% 50$ \\
\hline İletişim becerilerini geliştirmesi & $34 \% 63$ \\
\hline
\end{tabular}

Derslerde drama uygulamaları kullanmanın eğitim öğretimde ne gibi yararları olduğu sorulduğunda görüşü alınan öğretmenlerin görüş oranları \%63'lük oranla drama kullanıldığında öğrencilerde iletişim becerilerini geliştirmesi teması altında daha etkili iletişim kurma, empati geliştirme, sosyal ilişkilerde uyum gibi olumlu değişimler şeklinde ortaya çıkmıştır. Öğretmen görüşlerinin \%50'lik bir oranla dramanın yararını etkili öğretim sağlaması teması altında öğrenmede kalıcılık yarattığını, eğlenceli olduğundan katılımı artırdığını, soyut olayları/durumları somuta dönüştürdüğ̈̈ ve bunun öğrenmeyi kolaylaştırdığını ve yaşayarak öğrenme etkisi yarattığı şeklinde ortaya çıkmıştır. \%46'lık görüş oranı ile öğretmenler drama uygulamalarıyla öğrencinin başarma duygusu tatmalarına yardımcı olarak veya yaratıcılığı, hayal gücü ve kendini ifade etme becerisini geliştirerek öğrencide özgüven oluşturduğunu gözlemlediklerini belirtmişlerdir. \%31'lik görüş oranıyla öğretmenler, drama uygulamalarında öğrencilerin farklı karakterlere bürünerek gerçekleştirdikleri canlandırmaların duygudaşlık geliştirmelerine faydası olduğunu deneyimlediklerini belirtmiştir. Benzer şekilde \%27'lik görüş oranıyla öğretmenler dramalar sayesinde öğrencilerin takım olma bilinci kazandıklarını, grup olarak çalışmayı öğrendiklerini belirtmişlerdir. \%24'lük oranla öğretmenlerin drama uygulamalarında öğrencilerin derse aktif katılımının arttığını ve bunun da dersi daha geniş kitleye ulaştırmaya faydasının olduğunu belirtmiştir. Öğretmenler, dramanın, öğrencide hayal gücü ve yaratıcıllğı geliştirdiğini \%16'l1k görüş ortaklığ ile belirtmiştir. \%15'lik görüş oranıyla en düşük orana sahip değerlendirme ise drama uygulamalarının öğrencide duygusal zekâ gelişimine katkısı olduğu, davranış ve kişiliğinin şekillenmesine yardımcı olması hususundadır.

\section{Sonuç ve Tartışma}

Çalışma sonucuna göre bir eğitim öğretim dönemi boyunca Türkçe derslerinde en çok öykü/olay canlandırması (33) kullanıldı ğı belirlenmiş̧tir. Rol oynama (11) etkinlikleri ve kukla oyunları (9) da yine sıkça kullanılan etkinliklerdir. Görüşmede ayrıca sosyodrama etkinliği (8) kadar resim yapma etkinliklerinin de (8) kullanıldığı belirlenmiştir. Derslerde doğaçlama (6), pandomim (5) ve rol değiştirme (5) etkinlikleri ayrıca müzikle drama (3) ve yaratıcı drama (2) etkinlikleri de gerçekleştiren öğretmenler olduğu belirlenmiştir. Sadece bir katılımcı da zihinde canlandırma (1) etkinliği yaptırdığını bildirmiştir.

Görüşme yapılan öğretmenlerin tamamına yakını drama etkinliklerinin Türkçe dersinin her aşamasında rahatlıkla kullanılabileceği konusunda hemfikirdir. Öğretmenlerin büyük bir çoğunluğunun dramanın faydaları konusunda bilgi sahibi olduğu görülmekte ve neredeyse tamamının derslerinde dramayı kullandıkları ortaya çıkmaktadır. Ancak \%33'lük bir oranla öğretmenlerin dramayı bir metin 
canlandırma etkinliği olarak kullandıkları göz ardı edilmemelidir. Bilindiği gibi Türkçe dersi bilgi değil beceri dersidir. $\mathrm{Bu}$ yönüyle de hayata dair uygulamaları temel alır, içinde barındırır. Bu yöntemle dil, kurallarıyla birlikte kullanım alanlarında doğrudan öğretilebilir. Kara'nın (2008: 35) belirttiği gibi; anlatım bozukluklarını, dil yanlışlıklarını, deyim ve atasözleri hatta soyut anlamlı karmaşık şiirler bile drama ile kolaylıkla anlatılabilir, dilin tüm güzellikleri yaşatılarak öğretilebilir. Sağlam (1997: 11) da yaptığı çalışmada, Harriet-Finlay Johnson'nın çocukların görerek ve yaparak daha iyi öğrendiklerine inandığını ve dramayı bilgiyi aktarmak için araç olarak kullandığını belirtmiştir.

Çalışma grubundaki Türkçe öğretmenlerinin çok farklı drama etkinlikleri kullandıkları ve dramanın faydaları konusunda bilgi sahibi oldukları ortaya çıkmaktadır. Derslerde drama uygulamaları kullanmanın ne gibi yararları olduğu sorulduğunda, görüşü alınan toplam 54 Türkçe öğretmeninin görüş̧lerinin dağılım oranına göre \%63'lük bir oranda öğrencilerde iletişim becerilerini geliştirdiği, $\% 50$ 'lik bir oranda etkili öğretim sağladığı, \%46'lık oranda ise öğrencide özgüven oluşturduğu belirtilmiştir. Benzer şekilde Başçı ve Gündoğdu (2011) araştırmalarında drama kullanımının iletişim ve kendini ifade becerilerini arttırdığını belirtmişlerdir. Benzer şekilde Türkçe öğretiminde Köklü (2003), dinlediğini anlamada dramatizasyonun etkisiyle ilgili çalışmasında, Karakuş (2000) da drama yönteminin yazma becerilerine etkisiyle ilgili çalışmasında elde edilen başarının geleneksel yöntemle anlatılan derslerdeki başarıdan daha fazla olduğunu belirlemişlerdir. Durmuş (2008) da yaptığı çalışmada drama uygulanan katılımcıların utangaçlık hissinin, Tanrıseven ve Aykaç (2002) da çekingenlik hissinin azaldığını bulgulamışlardır. Söz konusu çalışmalar öğretmen görüşlerini kanıtlar niteliktedir.

\%31'lik görüş oranıyla dramanın öğrencilerde empati becerisi geliştirdiği, \%27’lik görüş oranıyla takım olma bilinci kazandırdığını bildirmiştir. Çoban (2007) araştırmasının sonucunda drama uygulamalarına katılanların sosyal ve duygusal gelişim kaydettiklerini belirtmiştir. Bu durum, empati geliştirerek takım olma becerisinin gelişmesiyle benzerlik göstermektedir.

\%24'lük görüş oranıyla öğretmenlerin drama uygulamalarında öğrencilerin derse aktif katılımının arttığını ve bunun başarıyı olumlu etkilediğini, \%16'lık görüş oranıyla öğrencide hayal gücü ve yaratıcılığ 1 geliştirdiğini, \%15'lik görüş oranıyla drama uygulamalarının öğrencide duygusal zekâ gelişimine katkısı olduğunu, öğrencinin davranış ve kişiliğinin şekillenmesine yardımcı olarak kendini ifade etme becerisinin geliştiğini belirtmişlerdir. Öğretmenlerin drama uygulamalarının faydalarına dair belirttikleri hususlar Er'in (2003) çalışma sonuçlarıyla da uyumludur:

Nihai olarak öğretmenlerin drama uygulamalarına değer verdiği çünkü uygulama sonuçlarının olumlu etkilerini gözlemledikleri söylenebilir. Ancak eleştirel düşünme ve problem çözme, eski bilişsel süreçlerin farkına varma, bireyin kendini tanıması ve özellikle ahlaki değerlerin farkına varma hususlarında da eğitici dramanın kullanılabileceği öğretmenlerce göz önünde bulundurulmalıdır.

\section{KAYNAKÇA}

Aral, N. (2000). Eğitimde Drama. İstanbul: Ya-Pa Yayın Pazarlamacılık.

Ayranc1, Bağc1, B. (2019). Türk Dili ve Edebiyatı Öğretmenliği Pedagojik Formasyon Birimi Öğrencilerinin Değerler Eğitimi Drama Kullanımları, ASEAD, Cilt 6, Sayı 3, 129-139.

Bağdatlı, M. İ. (2010). Kâzım Karabekir'in Uygulamalarında Yaşayarak Öğrenme ve Eğitici Drama. İstanbul Üniversitesi ilahiyat Fakültesi Dergisi, (23), 121-140.

Başçı, Z.; Gündoğdu, K. (2011). Öğretmen Adaylarının Drama Dersine İlişkin Tutumları ve Görüşleri: Atatürk Üniversitesi Örneği. İlkögretim Online. 10 (2), 454-467.

Bayram, E. (1999). İlköğretimde Drama 1. Ankara: MEB Yayınları. 
Bozdoğan, Z. (1993). Yaratıcı Drama. Ankara: Nobel Yayın Dağıtım.

Çalışkan, N. ve Karadağ, E. (2005). Dramada Beden Dili. Gazi Üniversitesi Kırşehir Eğitim Fakültesi, Cilt 6, Say1 2, 103-113.

Çebi, A. (1996). Öğretim Amaçlı Yaratıcı Drama Yoluyla İmgesel Dil Becerisinin Geliştirilmesi, Yayımlanmamış Doktora Tezi, Ankara Üniversitesi Sosyal Bilimler Enstitüsü, Ankara.

Çoban, Ç., E. (2007). Sosyal Beceri Sorunu Olan Öğrenciler ve Annelerine Uygulanan Yaratıcı Drama Etkinlikleri Programının Öğrencilerin Sosyal Beceri Düzeylerinin Gelişimi Üzerine Etkisi, Yayınlanmamış Yüksek Lisans Tezi, Dokuz Eylül Üniversitesi Eğitim Bilimleri Enstitüsü, İzmir.

Durmuş, E. (2008). Yaratıcı Drama İle Bütünleştirilmiş Grupla Psikolojik Danışmanın Üniversite Öğrencilerin Utangaçlık düzeylerine Etkisi, Ankara Üniversitesi Eğitim Bilimleri Fakültesi Dergisi, 41/1, 93-114.

Er, A. (2003). Drama ve Dil Öğretimi: Dramanın Sözlü Dil Öğretiminde Etkisi. Kazım Karabekir Eğitim Fakültesi Dergisi, (8), 246-254.

Gönen, M. (1992). Çocuk ve Yaratıcılık. YA-Pa Okul Öncesi Eğitimi ve Yaygınlaştırılması Semineri. Bursa.

Gönen, M. ve Dalk1lıç, N. (1999). Çocuk Eğitiminde Drama Yöntem ve Uygulamaları. İstanbul: Epsilon Yayınları.

İsmihan, E. (1992). Dramatizasyonun Çocuk Eğitimindeki Rolü, Yayımlanmamış Yüksek Lisans Tezi, Gazi Üniversitesi Sosyal Bilimler Enstitüsü, Ankara.

Kandır, A. (2003). "Pandomim", Okul Öncesi Eğitimde Drama. Ankara: Kök Yayınları.

Kaner, S. (1990). Psikodrama-Kuram, Teknik ve Araçlar, Ankara Üniversitesi Ĕgitim Bilimleri Fakültesi Fakülte Dergisi, Cilt: 23 Sayı: 2, 457-480.

Kara, Ö. T. (2000). Türkçe Öğretiminde Dramatizasyonun Kullanılması, Yayımlanmamış Yüksek Lisans Tezi, Atatürk Üniversitesi Sosyal Bilimler Enstitüsü, Erzurum.

Kara, Ö. T. (2008, Ocak-Şubat). Dramayla Türkçe Öğreniyorum. Osmaniye Rehberi, 34-44.

Kara, Ö. T. (2010). Dramanın İlk Uygulamalrı: Türk Şamanları. Turkish Studies, Cilt:5 Sayı:2, 11801191

Kara, Y., Çam, F. (2007). Yaratıcı drama yönteminin bazı sosyal becerilerin kazandırılmasına etkisi, $H$. Ü. Ë̆itim Fakültesi Dergisi 32, 145-155.

Karadağ, E., ve Çalışkan, N. (2005). Ilköğretimde Drama. Ankara: Anı Yayıncılık.

Karakuş, F. (2000). Drama Yönteminin İlköğretim Beşinci Sınıf Öğrencilerinin Öykü Yazma Becerilerine Etkisi, Yayımlanmamış Yüksek Lisans Tezi, Çukurova Üniversitesi Sosyal Bilimler Enstitüsü, Adana.

Kavcar, C. (1988). Türkçe Öğretiminde Dramatizasyon Yöntemi, Türk Dilinin Öğretimi Toplantısı. Ankara Üniversitesi Eğitim Fakültesi Yayınları, 83-90.

Kaygana, M. ve Yapıcı, M. (2010). İdeolojik Bireylerin Yetiştirilmesinde Tiyatronun Rolü, Turkish Studies, 5(2), 573-602. 
Köklü, S. (2003). Türkçe Öğretiminde 7. ve 8. Sınıf Öğrencilerine Dinlediğini Anlama Davranışının Kazandırılmasına Dramatizasyonun Etkisi, Yayımlanmamı Yüksek Lisans Tezi, Marmara Üniversitesi Eğitim Bilimleri, İstanbul.

McCastlin, N. (1990). Creative Drama in The Classroom and Beyond, New York: Allyn\&Bacon.

McCastlin, N. (2000). Creative Drama in Primary Grades, Longman Inc, New York.

Nutku, Ö. (1976), Teaching Drama (Çev. Tülin Şener, Filiz Koç Materyal), Ma. M. Educ., London.

Nutku, Ö. (1983). Dram Sanat1, İzmir: 9 Eylül Üniversitesi Yayınevi.

Nutku, Ö. (2001). DramSanatı Tiyatroya Giriş, İstanbul: Kabakı Yayınevi.

O'Neill, C. \& Lambert, A. (1990). Drama Structures A Practical Handbook For Teachers, London: Heinemann Educational Book Inc.

Ömeroğlu, E. (1991). Yaratıcı Drama Eğitiminin İngiltere'de Okul Öncesi Eğitiminde Kullanılmasıyla İlgili Bir İnceleme, YA-PA 7. Okul Öncesi Eğitim ve Yaygınlaştırılması Semineri. Eskişehir.

Önder, A. (2000). Yaşayarak Öğrenme için Eğitici Drama, İstanbul: Epsilon Yayınları.

Önder, A. (2004). Yaşayarak Öğrenme İçin Eğitici Drama, İstanbul: Epsilon Yayınları.

Sağlam, T. (1997). Eğitimde Drama ve Türk Çocuklarının Ritüel Nitelikli Oyunlarının Eğitimde Dramada Kullanımı Yayımlanmamış Doktora Tezi, Ankara Üniversitesi Sosyal Bilimler Enstitüsü, Ankara.

San, İ. (1990). Eğitimde Yaratıcı Drama, Eğitim Bilimleri Fakültesi Dergisi, Cilt: 23, Sayı:2, 573-574.

San, İ. (1991). Eğitim Öğretimde Yaşayarak Öğrenme Yöntemi ve Estetik Süreç Olarak Yaratıcı Drama. I. Eğitimde Nitelik Geliştirme, Eğitimde Arayışlar Sempozyumu, 13-14 Nisan, İstanbul, 261 266.

Şahin, F. T. (2003). Doğaçlama ve Rol Oynama, Ankara: Kök Yayınları.

Şimşek, T., \& Topal, Y. (2006). Türkçe Eğitiminde Drama ve Özgün Uygulama Örnekleri, Atatürk Üniversitesi Sosyal Bilimler Enstitüsü Dergisi, Cilt: 7/1, 277-297.

Şimşek, T., Topal, Y., Maden, S. ve Şahin, A. (2010). İlköğretim 2.Kademe Türkçe Dersinde Zarf Konusunun Drama Yöntemi Kullanılarak Öğretimi, Millî Eğitim-Eğitim ve Sosyal Bilimler Dergisi, (186), 106-120.

TDK. (1983). Türkçe Sözlük. Ankara: TDK Yayınları.

Ünal, İ. (2006). 6-8 Yaş Çocukları İçin Piyano Eğitimi Veren Kurumlarda Öğretmenlerin Başlangıç Aşamasında Piyano Öğretim Yöntemlerinden Biri Olarak Yaratıcı Dramaya İlişkin Görüşleri. Yayımlanmamış Yüksek Lisans Tezi, Eğitim Bilimleri Enstitüsü Dokuz Eylül Üniversitesi, İzmir. 